\title{
RAFAŁ WÓJCIK
}

\section{Marcin Wilkowski, Wprowadzenie do historii cyfrowej, Gdańsk: Instytut Kultury Miejskiej 2013, ss. 80}

Nakładem Instytutu Kultury Miejskiej w Gdańsku ukazał się w roku 2013 skrypt Marcina Wilkowskiego zatytułowany Wprowadzenie do historii cyfrowej. Publikacja dostępna jest wyłącznie online, na licencji Creative Commons Uznanie autorstwa - na tych samych warunkach 3.0 Unported (CC BY-SA). Konsultantami autora podczas przygotowywania książki byli Emanuel Kulczycki, Radosław Bomba oraz Marcin Werla, osoby $\mathrm{w}$ ostatnich latach zaangażowane $\mathrm{w}$ popularyzację wiedzy o nauce, wykorzystania nowych technologii w pracy naukowej, a także znające tajniki tej wiedzy od podszewki, wszyscy bowiem biorą udział w projektach odnoszących się do nowych form komunikacji, digitalizacji czy humanistyki w dobie internetu.

Marcin Wilkowski sam siebie określa jako badacza zainteresowanego „historia/pamięcią w perspektywie mediów (głównie internetu) i kultury popularnej, teorią historii oraz inspirowanymi przez Sieć nowymi zjawiskami na granicach systemu naukowego" ${ }^{\prime 1}$. Badaczom nowych mediów znany jest przede wszystkim jako inicjator bardzo ciekawego internetowego serwisu Historia i Media ${ }^{2}$. Zaangażowany jest także w projekty „Powstanie nie jest fajne" ${ }^{3}$ oraz THATCamp Polska ${ }^{4}$. Autor Wprowadzenia do

\footnotetext{
${ }^{1}$ Strona internetowa: http://wilkowski.org/ [dostęp: 23.07.2013].

${ }^{2}$ Historia i Media [online], [dostęp: 23.07.2013], dostępny w internecie: http://historiaimedia.org/.

${ }^{3}$ Godzina W [online], [dostęp: 23.07.2013], dostępny w internecie: http://godzinaw.pl/.

4 THATCamp Polska [online], [dostęp: 23.07.2013], dostępny w internecie: http:// thatcamp.pl/. THATCamp to otwarte spotkania o nieformalnym charakterze, których program tworzony jest przez uczestników danego wydarzenia. Opierają się na krótkich (dziesięciominutowych) prezentacjach, wolnych dyskusjach oraz udostępnianiu wykorzystanych materiałów online. Ruch ten postuluje wykorzystanie otwartego
} 
historii cyfrowej jest uczestnikiem Programu Doktorskiego Katedry Socjologii Collegium Civitas oraz pracownikiem Fundacji Nowoczesna Polska. Wszystkie te informacje wydają się istotne, ponieważ pokazuja że trudu napisania skryptu podjęła się osoba, która do tego zadania jest doskonale merytorycznie przygotowana. I rzeczywiście, jest to publikacja ze wszech miar godna uwagi.

Wprowadzenie do historii cyfrowej to książka niewielka, ma zaledwie 80 stron. A jednak pomimo tak skromnej objętości jest niezmiernie istotna, by nie rzec: pionierska na gruncie polskim. O pracy Wilkowskiego bardzo trudno pisać w krótkim omówieniu, ponieważ porusza on wiele kwestii, z których każda wymagałaby osobnego opracowania czy eseju. Zauważyła to zresztą w bardzo trafnym tekście Jak wykorzystać Wilkowskiego (w historii ksiażki)? Żaneta Kubic, która uważa, iż „większość założeń historii cyfrowej możemy bez obaw zastosować do bibliologii historycznej" 5 . Z tekstem Kubic warto się zapoznać, bowiem w zgrabny sposób podsumowuje wiele zagadnień dotyczących tego, co w książce Wilkowskiego można odnieść do bibliotekoznawstwa czy bibliologii.

Książka Wilkowskiego napisana została w sposób przejrzysty. Autor podzielił ją na 15 rozdziałów i uważam za zasadne przywołanie ich tytułów w niniejszym omówieniu:

1. Definiowanie cyfrowej historii;

2. Współczesny Internet z perspektywy historyka;

3. Digitalizacja i cechy formatu cyfrowego;

4. Wykorzystywanie repozytoriów cyfrowych;

5. Archiwa społeczne i oddolna digitalizacja;

6. Wyszukiwanie pełnotekstowe $\mathrm{w}$ archiwum cyfrowym i text mining;

7. Cyfrowe dziedzictwo;

8. Instytucje pamięci w kulturze cyfrowej;

9. Domena publiczna i jej blokowanie;

10. Historiografia poza drukiem;

dostępu oraz wolnych licencji, a także skupia się na wykorzystaniu nowych technologii w prowadzeniu badań humanistycznych i tworzeniu projektów kulturalnych. Promuje tzw. cyfrową humanistykę (digital humanities) oraz stara się zintegrować środowisko polskich badaczy sieci i zjawisk w niej występujących. Po raz pierwszy THATCamp odbył się w 2008 roku w USA i był zorganizowany przez Center for History and New Media (Uniwersytet George'a Masona). Strona ogólnoświatowego ruchu: http://thatcamp.org/ [dostęp: 23.07.2013]. Zarówno na polskiej, jak i na amerykańskiej stronie można zapoznać się z głównymi założeniami, ideą oraz programami dotychczasowych spotkań.

${ }^{5}$ Ż. Kubic, Jak wykorzystać Wilkowskiego (w historii ksiażki)? [online], [dostęp: 23.07.2013], dostępny w internecie: http://artykuly.bibliosfera.net/2013/07/jak-wykorzystac-wilkowskiego-w-historii-ksiazki/. 
11. Wizualizacje - historia poza tekstem;

12. Nowoczesne czasopisma naukowe online i open access;

13. Praca grupowa i nauka obywatelska;

14. Nowe internetowe formy komunikacji naukowej;

15. Otwartość w nauce i edukacji historycznej.

Całość kończy krótki biogram autora.

Spis treści pokazuje, jak szerokie spektrum tematów omawia Wilkowski w swoim skrypcie. Prawdą jest, iż właściwie każdy z nich wymagałby opracowania osobnego, jednak w kompendium, w moim odczuciu, omówione one zostały w sposób jasny i skondensowany. Nadto język Wilkowskiego jest przystępny i jego pracę czyta się bardzo dobrze i płynnie.

Wprowadzenie do historii cyfrowej jest książką bardzo ważną. Choć autor $\mathrm{w}$ tytule pisze o historii, to jednak zagadnienia $\mathrm{w}$ niej przedstawione dotykają właściwie wszystkich kluczowych tematów odnoszących się nie tylko do humanistyki cyfrowej (o której status, sens istnienia jako osobnej dyscypliny toczy się zresztą spór wśród badaczy ${ }^{6}{ }^{6}$, ale też do humanistyki w ogóle. Czy tego chcemy, czy nie, właściwie wszystkie dziedziny nauk humanistycznych znajdują się obecnie w dokładnie takiej samej sytuacji jak historia, a narzędzia cyfrowe i nowe technologie, które dostępne są historykom, mają do dyspozycji również badacze innych dyscyplin.

Czyż o zdefiniowanie cyfrowej filologii nie mogliby się pokusić filologowie?7 Czy rozdział Wspótczesny Internet z perspektywy historyka nie mógłby zostać napisany przez bibliotekoznawcę, filologa, socjologa? Każdy z omówionych przez Wilkowskiego tematów bliski jest chyba wszystkim przedstawicielom nauk humanistycznych i choć opisane one zostały przez historyka, w moim głębokim przeświadczeniu Wprowadzenie do historii cyfrowej może skłonić wszystkich badaczy do refleksji nad ich osobistym stosunkiem do nowych technologii, może stanowić inspirację, punkt wyjścia do własnych rozważań i dalszych poszukiwań. Ponadto stanowi nieocenioną pomoc w pracy ze studentami. Przystępna forma, klarowny język, a także, co jest istotne, bibliografia najważniejszych publikacji odnoszących się do każdego spośród 15 zagadnień omówionych

${ }^{6} \mathrm{Z}$ polskich publikacji poświęconych digital humanities warto odnotować Zwrot cyfrowy w humanistyce, red. A. Radomski, R. Bomba, Lublin 2013. Książka dostępna online $\mathrm{w}$ formatach PDF, ePUB i MOBI pod adresem: http://e-naukowiec.eu/zwrot-cyfrowy-w-humanistyce/ [dostęp: 26.07.2013].

7 Porównaj m.in. „Digital Medievalist Journal”, czasopismo mediewistów zainteresowanych wykorzystaniem nowych technologii w pracy i badaniach nad rękopisami średniowiecznymi, albo nowo powstałe czasopismo „Digital Philology: A Journal of Medieval Cultures" (The Johns Hopkins University Press). 
przez Wilkowskiego - wszystko to sprawia, że Wprowadzenie... powinno być lekturą obowiązkową zarówno badaczy, jak i studentów wszystkich chyba kierunków studiów humanistycznych (choć nie tylko, w moim odczuciu uwagi zaangażowanego i zainteresowanego historyka winny być bezcenne dla przedstawicieli branży IT, którzy programuja, tworzą bazy, programy, narzędzia dla humanistów). Wprowadzenie... powinno być lekturą obowiązkową dla humanistów wszystkich dziedzin dopóty, dopóki swojego osobnego spojrzenia nie wypracują także oni i dopóki nie powstanie Wprowadzenie do filologii/archeologii/bibliologii/wstaw-co-nale$\dot{z} y$ cyfrowej. Wiele wskazuje na to, że podobne publikacje odnoszące się do tych wszystkich dziedzin być może ujrzą wkrótce światło dzienne, jeśli tylko znajdzie się zapaleniec pokroju Wilkowskiego, który będzie jednocześnie równie dobrze jak on merytorycznie przygotowany do $\mathrm{w}$ istocie ogromnej pracy. Skrypt Wilkowskiego jest bowiem znakomitą synteza, która porusza wszystkie najważniejsze kwestie dotyczące badań na styku metodologii badań historycznych i badań internetu.

Wprowadzenie do historii cyfrowej wydaje się szczególnie ważne dla bibliotekarzy, bibliotekoznawców, bibliologów. Wszystkie tematy, które Wilkowski omawia, są ważne i właściwe dla osób pracujących w bibliotece, zwłaszcza $\mathrm{w}$ burzliwym okresie intensywnych przemian związanych z digitalizacja, tworzeniem repozytoriów cyfrowych, refleksją odnoszącą się do archiwów społecznych, a także w definiowaniu i nawiązywaniu współpracy z oddolnymi, obywatelskimi lub prywatnymi projektami digitalizacji różnych materiałów i dokumentów ${ }^{8}$. W istocie bowiem praca "historyka cyfrowego" (lub lwia jej część) byłaby niemożliwa, gdyby nie „cyfrowi bibliotekarze". I to właśnie między innymi bibliotekom, a właściwie czterem rodzajom instytucji określanych jako GLAM (Galleries, Libraries, Archives, Museums) poświęcony jest rozdział ósmy: Instytucje pamięci w kulturze cyfrowej.

Wilkowski nie tylko dostrzega przeobrażenia, jakim uległy wszystkie rodzaje tych instytucji, ale też podkreśla ich wagę i znaczenie również dla perspektywy badawczej historyka cyfrowego. Od roli, jaką GLAM odgrywa w udostępnianiu treści, które dotąd leżały ukryte przed okiem profanów w magazynach „instytucji zamkniętych, niedostępnych, posiadających niemal sakralny status" (s. 50), już tylko krok do znaczenia, jakie biblioteki (szczególnie amerykańskie i brytyjskie - Biblioteka Kongresu,

${ }^{8}$ Porównaj np. strony: www.zinelibrary.pl [dostęp: 26.07.2013] (udostępnia pisma tzw. trzeciego obiegu w Polsce, które w szczątkowy sposób były dotąd gromadzone przez biblioteki) albo www.komiksowekronikipoznania.pl [dostęp: 26.07.2013] (projekt digitalizacji prasowych seriali obrazkowych z prasy i czasopism poznańskich z lat 1918-1939 powstały jako owoc współpracy Biblioteki Uniwersyteckiej i Fundacji Tranzyt w ramach jej projektu Centrala - Mądre Komiksy). 
National Archives and Records Administration, British Library oraz The National Archives) mają w propagowaniu idei otwartości, wolnego dostępu oraz wypracowywania nowych dróg (i prawa) w udostępnianiu wszelkich treści gromadzonych w bibliotekach i innych instytucjach państwowych, jak galerie, archiwa czy muzea. A w wypadku udostępniania treści $\mathrm{w}$ domenie publicznej dzieli nas krok od zagadnień związanych z prawem autorskim. Wszystkie te problemy Wilkowski omawia w trafny sposób i umiejętnie wypunktowuje najważniejsze ich aspekty.

Oczywiście, część tematów, które Wilkowski porusza, znana jest doskonale bibliotekarzom i bibliotekoznawcom. Autor Wprowadzenia... wielokrotnie powołuje się zresztą na prace naukowców z tego kręgu badawczego, a także innych - socjologów, badaczy komunikacji, teoretyków i praktyków działań związanych z digitalizacją itd.

Przywoływana wcześniej Kubic zwraca uwagę na dwa schematy formuły pracy historyka zestawione przez Williama J. Turkela, Kevina Kee i Spencera Robertsa, a przywołane we Wprowadzeniu do historii cyfrowej (s. 54) $)^{9}$ i porównuje je z pracą historyka książki oraz wpisuje w szerszy problem oferty dydaktycznej współczesnych instytutów bibliotekoznawstwa i informacji naukowej. W istocie jednak owe standardy, a także pytania, które Kubic zadaje - w jaki sposób, gdzie oraz od kogo młodzi ludzie mają zdobywać wiedzę o tych nowych standardach - wydają się trafne odnośnie do wszystkich nauk.

Po lekturze skryptu Wilkowskiego czuje się oczywiście niedosyt ze względu na skondensowane potraktowanie tematów, z których każdy doczekał się obszernych opracowań innych autorów, w większości zagranicznych. Jest to jednocześnie ogromna zaleta tej publikacji, bowiem stymuluje czytelnika do własnych poszukiwań, co czyni z niej lekturę bardzo inspirującą. Co istotne, Wprowadzenie do historii cyfrowej jest dziełem otwartym w całym tego słowa znaczeniu. Autor zamierza aktualizować publikację jeden-dwa razy do roku, co doskonale wpisuje się w standard współpracy z innymi badaczami tej tematyki, których zresztą Wilkowski do kooperacji zaprasza.

Podsumowując, Wprowadzenie do historii cyfrowej jest lekturą obowiązkową dla każdego, komu zagadnienia z kręgu humanistyki cyfrowej, digitalizacji, otwartego dostępu, informacji naukowej, historii, czy też $\mathrm{w}$ ogóle miejsca humanistyki $\mathrm{w}$ nowej cyfrowej erze nie są obojętne. W moim przekonaniu lektura tego skryptu, a także śledzenie jego zapowiadanych aktualizacji, winna być obowiązkowa na wszystkich kierunkach studiów humanistycznych.

${ }^{9}$ W.J. Turkel, K. Kee, S. Roberts, A method for navigating the infonite archive, w: History in the Digital Age, red. T. Weller, London-New York 2012, s. 61-75. 
